\title{
Комплексна екологічна оцінка впливу системи «автомобіль-дорога-середовище» на об'єкти навколишнього природного середовища
}

\author{
Г.В. Аболмасова ${ }^{1}$, Л.А. Пісня ${ }^{1}$, І.А. Черепньов ${ }^{2}$ І І.В. Калінін ${ }^{3}$ \\ ${ }^{1}$ Науково-дослідна установа «Український науково-дослідний інститут \\ екологічних проблем» (м. Харків, Україна), abolmasova.anna@ukr.net \\ 2 Харківський національний технічний університет сільського господарства \\ імені Петра Василенко (м. Харків, Україна), voenpred314@ukr.net \\ ${ }^{3}$ Військовий інститут танкових військ Національного технічного університету \\ «Харківський політехнічний інститут» (м. Харків, Україна), kalina7164@ukr.net
}

\begin{abstract}
У статті розкрито комплексний підхід до оцінки впливу діяльності автомобільної дороги на навколишнє природне середовище, який базується на застосуванні методу аналізу ієрархії (MAI) Т.Сааті та реалізує експертно-аналітичний підхід. В результаті дослідження розроблено складну чотирьохрівневу ієрархічну структуру у вигляді просторової системи «автомобіль-дорога-середовище» (АДС). Побудова ієрархічної структури впливу дозволяє наглядно-просторово зрозуміти всі взаємовпливи елементів та їх взаємозалежність. Рівні ієрархічної структури побудовані у вигляді логічного концепту: «мета $\rightarrow$ субкритерії оцінки $\rightarrow$ фактори впливів $\rightarrow$ параметри впливів $\rightarrow$ складові довкілля, що зазнають впливу». Значення вагових коефіцієнтів, отриманих в результаті експертно-аналітичного оцінювання застосуванням програми розрахунків, що реалізує МАІ дозволило зробити переконливий висновок у доцільності врахування біотичної складової придорожнього простору, що до цього часу не враховувалося. Значення отриманої оцінки загального впливу від діяльності АДС на живі організми склало 50,86\%, тому оцінювання забруднення повітря, води та ґрунту без урахування біотичної складової не $є$ достатньою та об’єктивною.

Також зазначено, що розроблений комплексний ієрархічний підхід до оцінки АДС із застосуванням MAI, потребує подальшого уточнення кількісних характеристик впливу на складові довкілля шляхом лабораторних досліджень біотичних компонентів та ґрунту придорожнього простору за стандартизованими методиками.
\end{abstract}

Ключові слова: система «АДС», фрактори впливу, ваговий коефріцієнт, довкілля, об'єкт впливу, ієрархічна система, екологічна оцінка впливу.

Постановка проблеми. Важко уявити собі наше повсякденне життя без автомобільного транспорту, але поряд з усіма перевагами, які надає автомобілізація вона в той самий час завдає суттєвої шкоди довкіллю. Наразі спостерігається постійне зростання кількості автомобільного транспорту, так за даними Аналітичного агенства «АВTOCTAT» $з$ січня по вересень 2019 року в усьому світі було реалізовано майже 67 млн нових автомобілів. В Україні обсяг ринку нових легкових автомобілів за підсумками січня - вересня 2019 року склав 63,4 тис. одиниць, що майже на $12 \%$ більше показника річної давності. Минулого місяця українці придбали та зареєстрували майже 9 тисяч нових легкових авто, в результаті чого жовтневий ринок цього року, у порівнянні до жовтня минулого року, виріс майже на чверть [1].

Невпинний ріст автотранспортних засобів неминуче призводить до розширення дорожньої мережі у всьому світі, внаслідок чого збільшується навантаження на довкілля. На рис. 1 представлені схеми уявлень про взаємовпливи у системі «автомобіль-дорога-середовище». Запропо- нований комплексний підхід до дослідження в області впливу системи АДС на навколишнє природне середовище (НПС) з цілісним урахуванням всіх фракторів взаємовпливу, всіх елементів системи АДС, всіх умов формування та розповсюдження забруднення, 3 можливістю виявлення відповідальності за забруднення схематично зображено на рис. 1 частина б).

Також необхідно відмітити, що запропонована схема підходу до визначення взаємовпливів в системі АДС [2]:

- дозволяє чітко розмежувати відповідальність за забруднення НПС та реалізувати принцип «забруднювач платить»;

- дозволяє розглядати процес розповсюдження забруднень від елементів системи АДС у вигляді ієрархічної багаторівневої структури, наприклад шляхом використанням для їх оцінювання методу аналізу ієрархій Т.Сааті;

- вказує межі компетенції та можливості контролю за кількісними та якісними показниками впливу на НПС всіх елементів системи АДС та відповідно з цим вживати засоби щодо ефектив- 
ності зменшення екологічного ризику від діяльності автомагістралей.

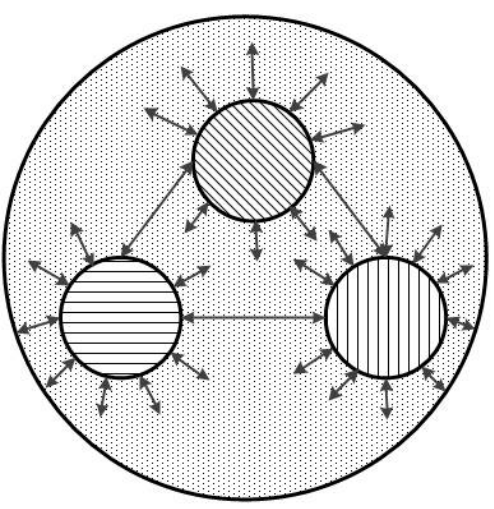

a
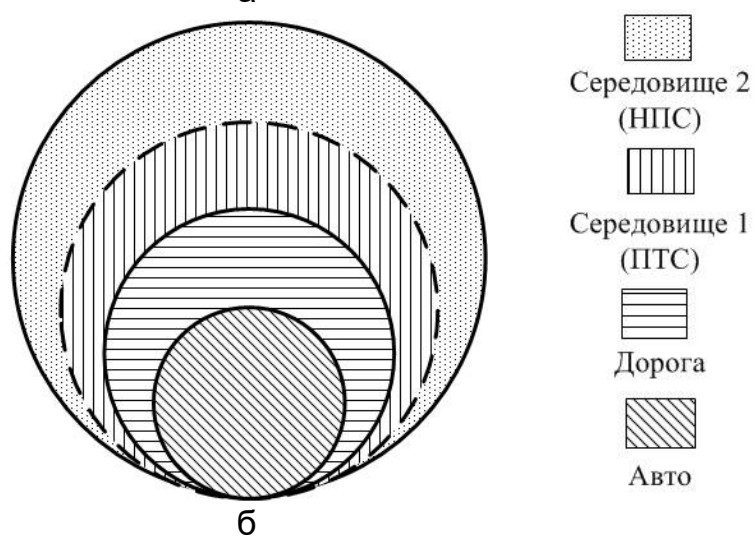
(HIIC)

Середовище 1 (ПТС)

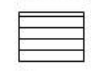

Дорога

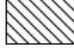

Авто

Рис. 1. Схеми взаємовпливів в системі «автомобіль-дорога-середовище»

(існуючий (а) та пропонуємий (б) підходи).

Сучасна транспортна політика розвинених держав спрямована на розвиток міжнародних транспортних коридорів, зокрема в автотранспортній галузі, сутність яких полягає в комплексному обліку максимально можливого впливу в процесі діяльності автомобільних доріг.

Щорічно в Україні кількість автомобільних доріг збільшується приблизно на 500 км., при цьому тільки на 1 км. відводиться приблизно 2-7 гектари земельних угідь. На рис.2 представлено зонування в системі АДС з доопрацюваннями авторів в наданій у [3]. Смуга відводу залежить від цінності земельних угідь і категорії автомобільної дороги.

Аналіз останніх досліджень. Наразі питання взаємовпливу системи «автомобіль-дорога-довкілля» $є$ одним з актуальних екологічних проблем сучасності. Зокрема, в роботах Луканіна В.Н., Кавтарадзе Д.Н., Ніколаєвої Л.Ф., Каніло П.М., Короновського Н.В., Желновач Г.М. розглянуто процеси розповсюдження та трансформації транспортних забруднень, вплив їх на біоту придорожніх зон [4-9]. Визначенням шляхів зменшення шкідливості викидів та питанням захисту довкілля від

забруднень в різні часи займались вчені: Зеркалов Д.3., Гриценко А.В., Внукова Н.В., Франчук Г.М., Архіпова Г.І., Угненко Є.Б.[10-17].

Проблемам, пов'язаним з розвитком автомобільних доріг та їх постійно зростаючим впливом на довкілля, присвячено роботи таких вчених як Степура В.С., Внукова Н.В., Белятинський А.О., Желновач Г.М. [18-21].

Дослідженню фрізичних впливів від дорожньотранспортної мережі (шум, вібрація., ультразвук, інфрразвук) присвячено наукові праці Угненко Є.Б., Внукової Н.В., Іванова Н.І., Мініної Н.Н. [22-26]., а електромагнітного випромінювання від транспорту - Бажинова О.В., Смірнова О.П., Лелюхіна А.М. [27,28].

Аналіз існуючих наукових праць показав, що дослідження науковців в основному стосуються лише окремих фракторів впливу (транспорту чи автомобільної дороги) або декількох з них. Дослідження в області впливу дорожньо-транспортної мережі на навколишнє природне середовище 3 урахуванням всіх фракторів впливу, об'єктів впливу, умов його формування та розповсюдження на сьогодні не проводились, тому вони $€$ актуальними.

Мета досліджень. Комплексно дослідити вплив автомобільної дороги на навколишнє природне середовище в процесі діяльності у вигляді системи «автомобіль-дорога-середовище» 3 метою встановлення внесків кожного з елементів шляхом застосування методу аналізу ієрархій із отриманням результатів експертно-аналітичних оцінок.

Результати досліджень. Дорожньо-транспортна мережа включає цілий комплекс факторів впливу на навколишнє природне середовище (НПС), умов їх розповсюдження, накопичення та трансформації.

Розглядаючи автомобільну дорогу як самостійну споруду необхідно зазначити, що сама по собі вона не справляє значного впливу на довкілля, але все одно його необхідно брати до уваги. Одразу ж після введення дороги в експлуатацію відбуваються процеси міграції хімічних елементів з в'яжучих матеріалів, що проявляється у випаровуванні їх з поверхні дорожнього полотна та перемішуванні часток в атмосфері, а саме у приземному шарі повітря. Серйозною проблемою $€$ те, що автомобільна дорога може перетинати шляхи міграції тварин та фрагментувати їх середовище існування, поділяючи їх при цьому на дрібні та ізольовані частини, що в кінцевому випадку може призвести до зникнення популяції [29].

Вплив експлуатації автомобільної дороги на довкілля необхідно розглядати в тандемі з транспортними засобами. Навіть сам рух транспорту 
по полотну дороги негативно впливає на довкілля, відлякуючи тварин тим самим змінюючи їх поведінку та середовище існування, а також викликаючи ризик їх травмування та загибелі.

Але все ж таки традиційно до значних фракторів впливу автодорожнього комплексу відносять шкідливі викиди від автомобільного транспорту:

- відпрацьовані гази (ВГ) автомобілів, що надходять до НПС через вихлопну трубу і складають 60 \% від усіх газоподібних викидів;

- картерні гази, що складаються з суміші частки ВГ, яка потрапила до картеру двигуна через нещільність поршневих кілець, та парів мотор- ного масла. Складають 20 \% від загальної кількості газоподібних викидів;

- пари вуглеводнів з паливного баку, трубопроводів та карбюратора, які складають 20 \% від усіх газоподібних викидів.

Наразі, транспортно-експлуатаційний стан автомобільних шляхів в нашій країні не є задовільним. Близько 51 \% від загальної протяжності доріг не відповідають вимогам за рівністю та 39,2 \% - за міцністю. Це призводить до того, що автомобілі вимушені рухатись в режимі розгін-гальмування, а як відомо саме при такому режимі спостерігається найбільший викид шкідливих речовин [30].

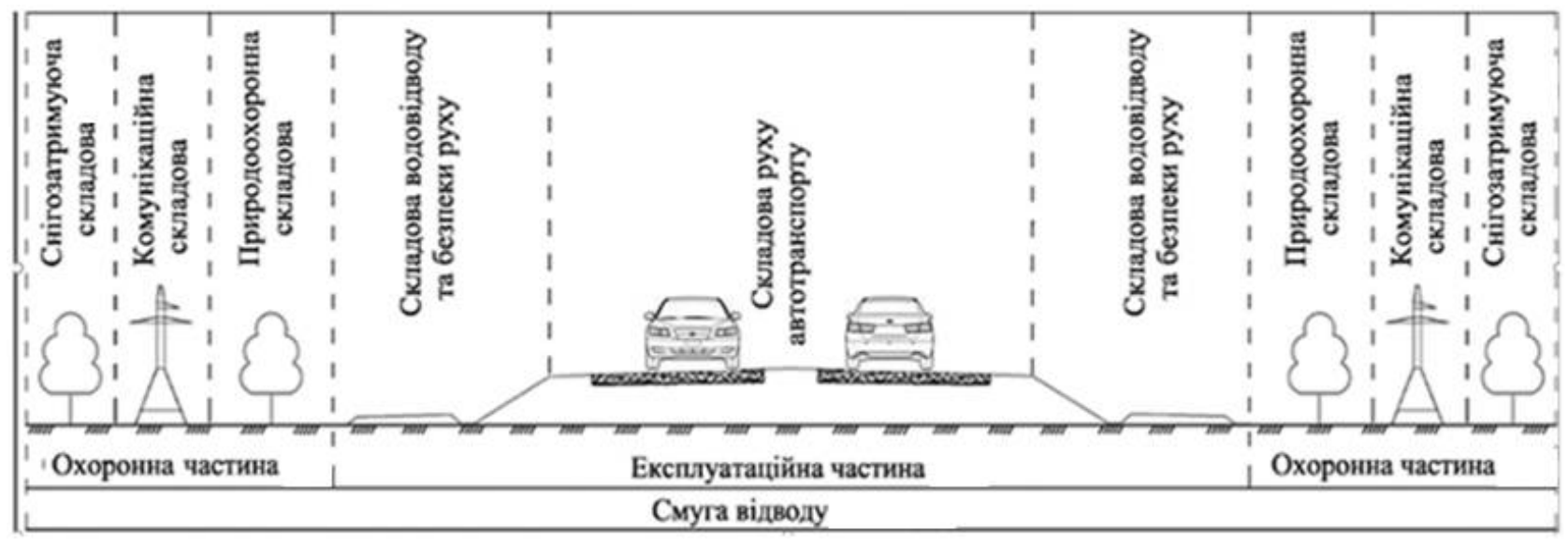

Рис. 2. Зонування в системі «автомобіль-дорога-середовище»

На відміну від інших видів транспорту автомобільний транспорт $є$ більш агресивним по відношенню до НПС, будучи потужним джерелом його забруднення. Питома вага шкідливих транспортних викидів вже перевищила аналогічні показники в енергетиці, металургії, газової та багатьох інших галузях промисловості. Доля забруднень, що вносяться автомобільним транспортом до атмосфери становить приблизно $50 \%$, а для міст та промислових центрів вона сягає до 75-90 \% від загального рівня забруднень.

Відпрацьовані гази двигунів містіть більше 1000 речовин, з яких тільки 280 розпізнано, багато з яких $€$ токсичними та канцерогенними. Через велике різноманіття та складність розпізнавання деяких з них, до розгляду зазвичай приймаються більш вивчені компоненти та з'єднання, серед яких: окис вуглецю, вуглеводні, окисли азоту, ароматичні альдегіди, формальдегід, сірчистий ангідрид, бенз(а)пірен, сажа, оксиди сірки, азот, кисень, водяний пар та ін. Поряд з цим, при роботі автомобільного транспорту відбувається поглинання ним великої кількості кисню, необхідного для запуску процесів згоряння палива. Лише один автомобіль за один рік регулярної експлуатації знищує більше 4 тон кисню.
Також значними фракторами впливу автодорожнього комплексу є пил, утворений під час руху транспорту, а саме:

- пил від автопокришок під час тертя їх о покриття дороги;

- пил від зносу автотранспортних засобів та в результаті тертя деталей між собою;

- пил від стирання та викришування покриття автомобільної дороги.

Утворення пилу призводить до значного запилення приземного шару атмосфери, ґрунту та рослин придорожнього простору. Небезпечним $\epsilon$ те, що до складу пилу входять важкі метали, що справляють токсичний вплив на компоненти довкілля. Не варто залишати без уваги також і негативний вплив поверхневого стоку з автомобільних доріг, до складу якого входять завислі речовини, нафтопродукти та важкі метали. Взимку до них ще додаються хімічні речовини, що входять до складу протиожеледних реагентів.

Фізичні фактори, такі як шум, світло фрар, вібрація, електромагнітні поля, теплові викиди від автотранспорту не завжди доступні для прямого сприйняття, але втім не менш шкідливі для довкілля.

Транспортний шум виникає під час роботи двигунів, гальм, колес, а також спричинений 
аеродинамічними властивостями транспортного засобу, та залежить від типу транспорту (легковий автомобіль, вантажний автомобіль, мотоцикл) [31]. Але все ж таки при русі автомобіля зі швидкістю більше 50 км/год переважаючим $€$ шум спричинений шинами автомобіля, який збільшується пропорційно до швидкості руху.

Вібрація при русі транспортного засобу виникає під час дії відцентрових сил, що викликані дисбалансом обертових вузлів (коленвалів, маховиків, зчеплення, карданний вал, вентилятори радіатора та обігрівача, гальмівні диски та барабани, шини) та великою різницею мас рухомих деталей (поршні та шатуни мотору). Вирізняють наступні причини дисбалансу: конструктивні (обумовлені особливостями в конструкціях деталей); технологічні (пов'язані з наявністю допустимих відхилень параметрів і розмірів деталей); експлуатаційні (нерівномірний знос деталей, їх деформація або дефекти) [32].

Також не останню роль у виникненні вібрації відіграє нерівномірність дорожнього покриття. Коливання, які при цьому виникають, через кузов автомобіля передаються на покриття автомобільної дороги і далі на елементи придорожнього простору, негативно впливаючи на них. Будівництво автомобільної дороги та в подальшому рух по ній транспортних засобів призводить до ущільнення ґрунтових мас, що у свою чергу викликає порушення водного балансу підземних вод. Через це виникають підтоплення, що впливає на стійкість автошляхів та призводить до їх руйнації.

Електромагнітне випромінювання від автотранспорту набуває в наш час нового значення завдяки дедалі більшому зростанню застосування електронних систем при управлінні транспортними засобами та збільшенню використання електромобілів. Джерела випромінювання електромагнітних хвиль від транспорту поділяють на первинні (система запалювання та електрообладнання) та вторинні (капот, елементи кузова, грати радіатора, деталі моторного відсіку, крила), що спричиняють негативний вплив на біоту придорожньої смуги [33].

Забруднення придорожньої смуги викликане також сміттям, що викидається учасниками руху у смузі відводу, залишками від аварій транспортних засобів та втратами різноманітних вантажів при їх транспортуванні.

Необхідно також зазначити, що рівень впливу автомобільної дороги на прилеглі території залежить не тільки від інтенсивності транспортного потоку, але й від природно-кліматичних умов. Стан забруднення приземного шару атмосфери притрасової смуги визначається викидами забру- днюючих речовин автотранспортом і фонової характеристикою місцевості.

Концентрація забруднюючих речовин в атмосорері від автомобільного транспорту за одного й того самого масового викиду може істотно змінюватись в залежності від природно-кліматичних факторів. Зазначені фактори в природному середовищі постійно змінюються тому розповсюдження різноманітних забруднень від автомобільної дороги відбувається в постійно нових умовах [4].

На рис. 3 приведена схема складових теплового та хімічного балансів для дорожньо-транспортної системи (в табл. 1 надано пояснення позначень складових теплового та хімічного балансів), з якої видно, що технологічна і природна підсистеми пов'язані між собою потоками речовини та енергії [34].

Таблиця 1. Складові теплового та хімічного балансів

\begin{tabular}{|c|c|}
\hline $\begin{array}{l}\text { По- } \\
\text { каз- } \\
\text { ник }\end{array}$ & Опис показника \\
\hline$g_{\text {T }}$ & $\begin{array}{l}\text { надходження до атмосфери від роботи } \\
\text { транспорту; }\end{array}$ \\
\hline$g_{F}$ & $\begin{array}{l}\text { надходження забруднюючих речовин від } \\
\text { інших джерел забруднення (фонова хара- } \\
\text { ктеристика місцевості); }\end{array}$ \\
\hline$g_{\text {д }}$ & $\begin{array}{l}\text { надходження забруднюючих речовин до } \\
\text { атмосфрери } 3 \text { верхніх шарів атмосфрери в } \\
\text { результаті дифруії газів; }\end{array}$ \\
\hline gy & $\begin{array}{l}\text { винесення речовини в результаті природ- } \\
\text { них процесів в атмосорері (вітер та ін.); }\end{array}$ \\
\hline $\mathrm{G}_{\mathrm{T}}$ & надходження до ґрунту від транспорту; \\
\hline $\mathrm{GF}_{\mathrm{F}}$ & $\begin{array}{l}\text { надходження свинцю через атмосферний } \\
\text { перенос від інших джерел, вимиванням } \\
\text { (під час дощу) або осадженням за рахунок } \\
\text { гравітаційних сил; }\end{array}$ \\
\hline $\mathrm{G}_{\mathrm{p}}$ & $\begin{array}{l}\text { винесення свинцю за допомогою рослин } \\
\text { притрасової смуги; }\end{array}$ \\
\hline $\mathrm{G}_{n}$ & $\begin{array}{l}\text { винесення свинцю до нижніх частин } \\
\text { ґрунту; }\end{array}$ \\
\hline $\mathrm{R}$ & $\begin{array}{l}\text { радіаційний баланс поверхні автомобіль- } \\
\text { ної дороги (ккал/см² за певний проміжок } \\
\text { часу); }\end{array}$ \\
\hline $\mathrm{B}$ & $\begin{array}{l}\text { теплообмін між поверхнею дорожнього по- } \\
\text { криття та атмосфрерою; }\end{array}$ \\
\hline S & $\begin{array}{l}\text { теплообмін між дорогою та основою } \\
\text { (ґрунтом); }\end{array}$ \\
\hline$t_{д}$ & $\begin{array}{ll}\text { температура } & \text { поверхні } \\
\text { покриття; } & \end{array}$ \\
\hline$t_{B}$ & температура атмосфрерного повітря. \\
\hline
\end{tabular}

Таким чином, експлуатація автомобільної дороги спричиняє на довкілля комплексний багатофа- 
кторний вплив, який доцільно розглядати у вигляді узагальненої структури системи «автомобіль-дорога-навколишнє природне середовище».

Це дозволить цілісно врахувати всі необхідні елементи (фактори впливу, об'єкти впливу, умови його формування та розповсюдження) для узагальненої оцінки всіх масштабів забруднення екосистем. На рис.4 зображена структура оцінки комплексного впливу експлуатації автомобільної дороги на об'єкти НПС.

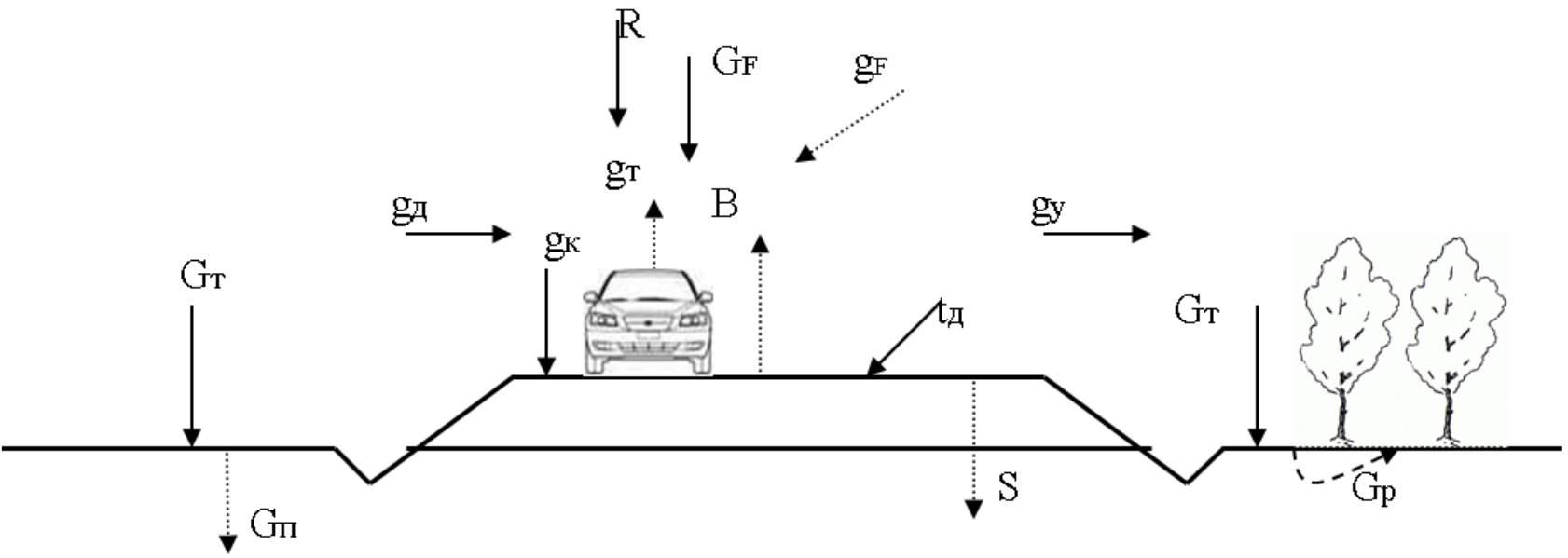

Рис. 3. Схема складових теплового та хімічного балансів для дорожньо-транспортної системи

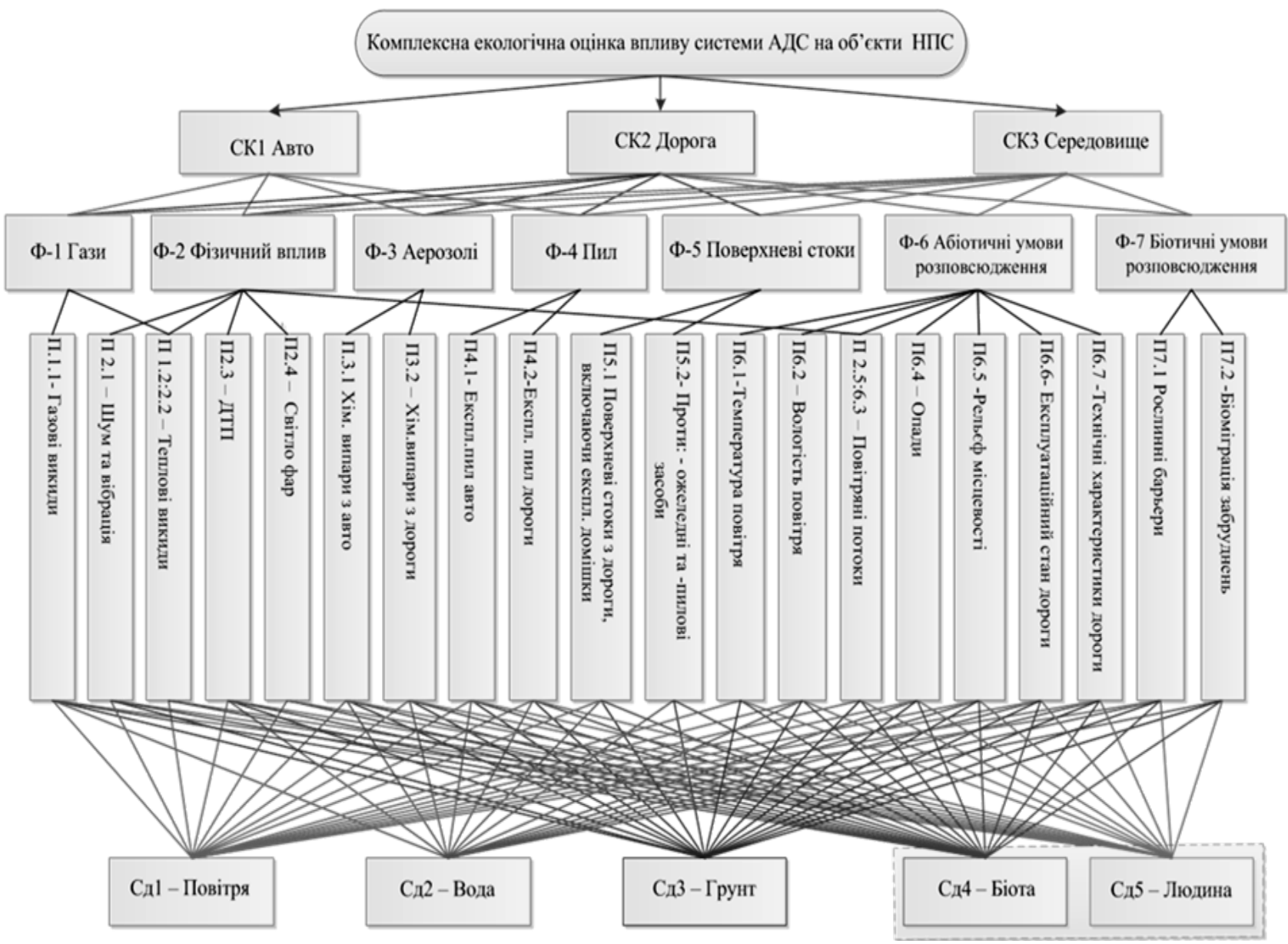

Рис. 4. Структура оцінки комплексного впливу автомобільної дороги на об'єкти НПС

Інженерія природокористування, 2019, №4(14), с. 75 - 85

Engineering of nature management, 2019, \#4(14), p. 75 - 85 
Рівні ієрархії системи АДС складаються з комплексу елементів, пов'язаних один з одним структурними взаємозв'язками, які характеризують та описують види впливів, їх природу, умови розповсюдження і накопичення, тощо. Необхідно звернути увагу, що до запропонованої ієрархії включено біотичні та абіотичні умови середовища, які мають досить суттєве значення у розповсюдженні впливу автомобільної дороги під час її експлуатації, але часто не враховуються у дослідженнях.

Комплексна оцінка впливу системи АДС на об'єкти НПС була проведена на основі методу аналізу ієрархій та включала експертно-аналітичне визначення вагових коефіцієнтів вкладу кожного елемента на загальний результат оцінки. Задля цього було використано авторську програму «MAl», яка реалізує відомий метод аналізу ієрархій Томаса Сааті з доопрацюваннями [35]. Перевага методу аналізу ієрархій полягає в можливості визначення вагових коефіцієнтів кожного елемента ієрархічної системи з урахуванням його взаємозв'язків і взаємовпливу шляхом попарно експертних порівнянь за шкалою Т.Сааті.

3 діаграми (рис. 5a) видно, що загальний вплив системи АДС на довкілля розподілився наступним чином: внесок авто складає $61,75 \%$, дороги $-29,69 \%$, а середовища $-8,56 \%$. Тобто врахування елемента "середовище», як такого, що сприяє розповсюдженню впливу, є необхідним.

На рисунку (рис. 5б) вказані вагові показники фракторів впливу системи АДС на навколишнє природне середовище. Можна побачити, що найбільшу вагомість серед факторів впливу мають гази і фізичний вплив зі значеннями $46,46 \%$ та $27,06 \%$ відповідно.

Також було визначено (рис. 5в) пріоритетність показників складових довкілля, що зазнають впливу від АДС, а саме: вплив на біоту складає $32,14 \%$ загального впливу, на повітря $31,52 \%$, людину - 18,72 \%, ґрунт - 13,97\% та воду $-3,65 \%$ [35].

Висновки. В результаті експертно-аналітичних оцінок комплексного дослідження впливу системи АДС на навколишнє природне середовище, шляхом застосування методу аналізу ієрархій, отримано внесок кожного з елементів в загальну структуру впливу.

Особливо важливим $є$ виявлений загальний вплив на живі організми, що складає $50,86 \%$, який вказує, що проведення оцінки діяльності автомобільної дороги шляхом визначення забруднення повітря, води та ґрунту без урахування біотичної складової не є достатньою та об'єктивною.

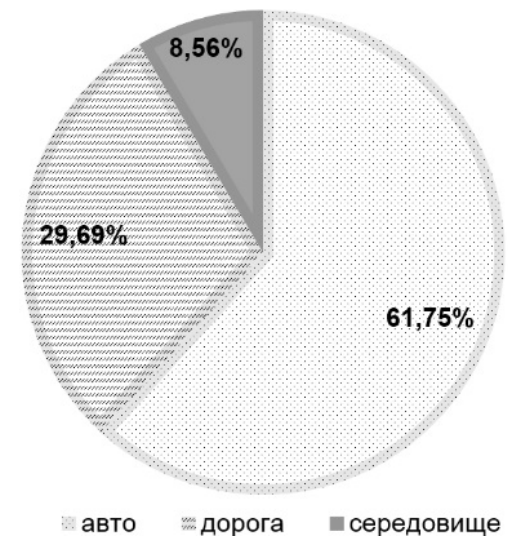

а) вагомість криеріїв в комплексній оцінці впливу на довкілля системи АДС

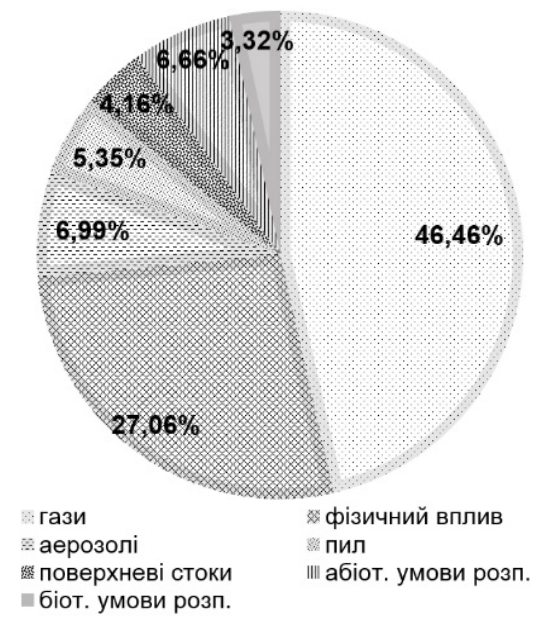

б) внесок показників, що характеризують фактори впливу на довкілля системи АДС

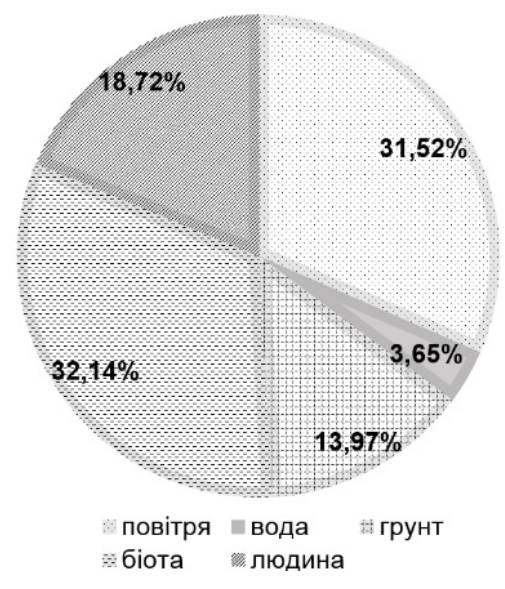

в) вагові показники складових довкілля, що зазнають впливу від АДС

Рис. 5. Результати комплексної екологічної оцінки впливу системи АДС на об'єкти довкілля 
Важливо зазначити, що розроблений комплексний ієрархічний підхід до оцінки системи АДС із застосуванням MAI, потребує подальшого уточнення кількісних характеристик впливу на складові довкілля шляхом лабораторних досліджень біотичних компонентів та ґрунту придорожнього простору за стандартизованими методиками. Отримані в подальшому графріки залежності накопичення у рослинності та ґрунтах забруднювачів дозволять використовувати відібрані для дослідження рослини у якості біоіндикаторів динаміки стану обраної ділянки дороги.

\section{Література}

1. Аналітичне агенство «АВТОСТАТ» [Електронний ресурс]. - Режим доступу: https://www. autostat.ru/.

2. Пісня Л. А. Новий підхід до забезпечення екологічної безпеки у системі «автомобіль-дорога-середовище»/ Л. А.Пісня, А.В. Аболмасова// Екологічна безпека: проблеми і шляхи вирішення: зб. наук, статей XIV міжнар. наук.-практ. конф., м. Харків, 10 - 14 верес. 2018 р. УКРНДІЕП. - ПП «Стиль-Іздат», 2018. С.247 - 251.

3. Ємець О.А. Кадастрове обґрунтування відведення земель при будівництві автомагістралей /О.А. Ємець // Міжнародний науковий журнал "Технологічний аудит та резерви виробництва" - 2014 - № 1/1(15). - С.20 - 23.

4. Луканин, В.Н. Промышленно-транспортная экология: Учеб. для вузов/ В.Н. Луканин, Ю.В. Трофименко; Под ред. В.Н. Луканина. - М.: Высш. шк., 2003. - 273 с.

5. Кавтарадзе Д.Н. Автомобильные дороги в экологических системах (проблемы взаимодействия) / Д.Н. Кавтарадзе, Л.Ф. Николаева, Е.Б. Поршнева, Н.Б. Флорова - М.: ЧеРо, 1999. - 240 с.

6. Канило П.М. Автомобиль и окружающая среда: учебное пособие / П.М. Канило, И.С. Бей, А. И. Ровенский - Харків: Прапор, 2000. - 303 с.

7. Короновский Н.В. Геология: Учеб. для эколог. специальностей вузов / Н.В. Короновский, Н.А. Ясманов. - М.: Изд. Центр «Академия», 2003. $-448 \mathrm{c}$.

8. Желновач Г.М. Оцінка ступеня техногенного навантаження на придорожній простір (на прикладі обходу м. Лубни)/Г.М, Желновач//Вісник кременчуцького національного університету імені Михайла Остроградського. - Кременчук: КрНУ, 2013. - Випуск 5 (82). - С. 156-159.

9. Каніло П.М. Канцерогенність відпрацьованих газів автомобілів / П.М. Каніло, К.В. Костенко, Н.В. Внукова, С.О. Коверсун // зб. наук. пр. / Харк. нац. автомоб.-дор. ун-т; [редкол.: А. Туренко (гол. ред.) та ін.]. - Х.: ХНАДУ, 2011. - Вип. 29. - C.160 -167.
10. Гутаревич Ю.Ф. Екологія та автомобільний транспорт: Навчальний посібник / Ю.Ф. Гутаревич, Д.В. Зеркалов, А.Г. Говорун, А.О. Корпач, Л.П. Мержиєвська - К.: Арістей, 2006. - 292 с.

11. Франчук Г.М. Урбоекологія і техноекологія: підруч. / Г.М. Франчук, О.І. Запорожець, Г.І. Архіпова. К.: Вид-во Нац. авіац. ун-ту «НАУдрук», 2011. - 496 с.

12. Архіпова Г.І Аналіз впливу відпрацьованих автомобільних газів на стан атмосферного повітря в густонаселених районах/ Г.І. Архіпова , І.С. Ткачук, Є.І. Глушков // Вісник НАУ. - 2009. - № 1. - С. 78 - 83.

13. Внукова Н.В. Вплив автомобільних доріг на екобезпеку комплексу «автомобіль-дорога-середовище» / Н.В. Внукова // Східно-Європейський журнал передових технологій. - 2011. - № 5/3 (53). - С. 43 - 46.

14. Зеркалов Д.В. Екологічна безпека та охорона довкілля: монографія/Д.В. Зеркалов. - К.: Основа, 2012. - 514 с.

15. Угненко Є.Б. Використання природних цеолітів для підвищення ефективності очищення стоків 3 автомобільних доріг / $€$.Б. Угненко, В.О. Юрченко, Н.І. Сорочук, О.Г. Мельнікова, М.В. Ячник // Автошляховик України. - 2015. - № 6. - С. 36 - 38.

16. Соловей В.В. Водородные экотехнологии - инновационная составляющая проблемы повышения экологической безопасности транспортной и стационарной энергетики / В.В. Соловей, А.В. Гриценко, Н.В. Внукова // Сборник научных трудов ХНАДУ «Автомобильный транспорт» - 2012 - №31. - С. 77- 82.

17. Гриценко А.В. Снижение эмиссии диоксида углерода на основе использования ветроводородных технологий / А.В. Гриценко, В.В. Соловей, Н.В. Внукова // Вестник ХНАДУ сб. науч. тр. - 2014. - Вып. 64. - С. 96 -102

18. Внукова Н.В. Показники впливу комплексу АДС на навколишнє середовище та методи їх оцінки/ Н.В. Внукова // Вестник ХНАДУ. - Харків: ХНАДУ, 2010. - № 51.- С. 173 - 179.

19. Внукова Н.В. Вибір екологічно значимих параметрів автотранспортних систем для оцінки екологічної небезпеки придорожнього простору / Н.В. Внукова, Г.М. Желновач // Екологічна безпека. - Кременчук: КрНУ, 2011. - №12. - C. 119 - 123.

20. Степура В. С. Основи експлуатації автомобільних доріг і аеродромів: навч. посіб. / В.С. Степура, А.О. Бєлятинський, Н.В. Кужель. - K.: HAY, 2013. - 204 c.

21. Внукова Н.В. Науково-методологічні основи екологічної безпеки комплексу автомобільдорога-середовище: автореф. дис. на здобуття 
наук. ступ. д.т.н.: спец. 21.06.01 «Екологічна безпека» / Внукова Наталія Володимирівна. - X: ХНАДУ. - 2015. - 36 с.

22. Внукова Н.В. Шумове забруднення примагістральних територій як фактор впливу на здоров'я населення (на прикладі смт Пісочин Харківської області) / Н.В. Внукова, Г.М. Желновач // Вестник ХНАДУ: сб. науч. тр. - 2008. - Вып. 43. - C. $13-15$.

23. Угненко Є.Б. Визначення акустичного забруднення придорожнього простору та основних шумових характеристик транспортного потоку/ Є.Б. Угненко, В.С. Гавриш // Науково-виробничий журнал Автомобільні дороги. Екологія - 2015 - № 6 (248). - C.39 - 41.

24. Внукова Н.В. Оцінка ризику акустичного та вібраційного забруднення придорожнього простору ділянки автомобільної дороги / Внукова Н.В., Желновач Г.М., Пархін Н.В. // Вестник ХНАДУ сб. науч. тр. - 2010. - Вып. 48. - С. 15 -19.

25. Минина Н.Н. Проблема снижения акустического воздействия на жилую застройку при проектировании, строительстве и функционировании транспортных сооружений: автореф. дис. д-ра техн. наук. - СПб., 2012. - 50 с.

26. Иванов Н.И. Инженерная акустика. Теория и практика борьбы с шумом / Н.И. Иванов // учебник. Университетская книга - М.: Логос $-2008 .-424$ c.

27. Бажинов О.В. Гібридні автомобілі / О.В. Бажинов, О.П. Смирнов, С.А. Сєріков, А.В. Гнатов, А.В. Колєсніков. - Харків: ХНАДУ, 2008. - 327 с.

28. Лелюхин А.М. Разработка методов оценки электромагнитных полей на объектах транспорта: автореферат дис. ... кандидата технических наук: 05.22.01 / Лелюхин Антон Михайлович; [Место защиты: Моск. гос. автомобил.-дорож. ин-т (техн. ун-т)]. - Москва, 2010. - 19 с.

29. Отчет об оценке воздействия на окружающую среду 002-17-ОВОС / Государственное предприятие «БЕЛГИПРОДОР» - Минск, 2017 $-301 \mathrm{c}$.

30. Ванчура Р. Аналіз вмісту важких металів у при магістральних землях Німеччини та порівняння з отриманими результатами в Україні / Р. Ванчура // Сучасні досягнення геодезичної науки та виробництва : збірник наукових праць Західного геодезичного товариства УТГК / Західне геодезичне товариство Українського товариства геодезії і картографії, Національний університет "Львівська політехніка" - Випуск 2 (24). - С. 191 - 194, 2012.

31. Гутаревич Ю.Ф. Екологія та автомобільний транспорт: навчальний посібник / Ю.Ф. Гутаревич, Д.В. Зеркалов, А.Г. Говорун, А.О. Корпач, Л.П. Мержиєвська. - Київ: Арістей, 2006 - 292 с.

32. Drive2 [Електронний ресурс]. - Режим доступу: https://www.drive2.ru/b/2423164/.
33. Павличенко А.В. Транспортна екологія. Методично-інформаційні матеріали до самостійного вивчення дисципліни та виконання індивідуальних завдань для студентів напряму підготовки 6.070101 Транспортні технології (за видами транспорту) / А.В. Павличенко, С.М. Лисицька, О.О. Борисовська, О.В. Деменко. - Д.: Національний гірничий університет, 2012. - 39 с.

34. Халилова Р.Х. Экологические проблемы автомобильных дорог, производственных предприятий дорожного строительства и пути их решения: автореферат дис. ... доктора технических наук: 03.00.16 / Халилова Рахима Хамитовна; [Mесто защиты: Моск. государственный университет природообустройства]. - Москва, 2001. - 44 с.

35. Аболмасова Г.В. Елементи інтегрального підходу в екологічній оцінці стану забрудненості придорожнього простору / Г.В. Аболмасова, Л.А. Пісня, О.В. Черба // Екологічна безпека: проблеми і шляхи вирішення: зб. наук, статей XV міжнар. наук.-практ. конф., м. Харків, 9 -13 верес. 2019 р. УКРНДІЕП. - ПП «Стиль-Іздат», 2019. - С.5 - 8.

\section{References}

1. Analytic agency «Autostat» (2019). Available at: https://www.autostat.ru/ (Accessed: 3 December 2019).

2. Pisnia, L. A. and Abolmasova, A. V. (2018) 'Novyi pidkhid do zabezpechennia ekolohichnoi bezpeky u systemi «avtomobil-doroha-seredovyshche»', in Ekolohichna bezpeka: problemy $i$ shliakhy vyrishennia. UKRNDIEP Kharkiv: StylIzdat, pp. 247 - 251.

3. Yemets, O. A. (2014) 'Kadastrove obgruntuvannia vidvedennia zemel pry budivnytstvi avtomahistralei', Tekhnolohichnyi audyt ta rezervy vyrobnytstva, (1/1(15)), pp. 20 - 23.

4. Lukanyn, V. N. and Trofymenko, Y. V. (2003) Promyshlenno-transportnaia ekolohyia. Vysshaya shkola. Moscow. p. 273.

5. Kavtaradze, D. N. et al. (1999) Avtomobylnye dorohy $v$ ekolohycheskykh systemakh (problemy vzaymodeistvyia). Moscow: CheRo. p. 240.

6. Kanylo, P. M., Bei, Y. S. and Rovenskyi, A. Y. (2000) Avtomobyl y okruzhaiushchaia sreda. Kharkiv: Prapor. p. 303.

7. Koronovskyi, N. V. and Yasmanov, N. A. (2003) Heolohyia. Moscow: Tsentr «Akademyia». p. 448.

8. Zhelnovach, H. M. (2013) 'Otsinka stupenia tekhnohennoho navantazhennia na prydorozhnii prostir (na prykladi obkhodu m. Lubny)', Visnyk kremenchutskoho natsionalnoho universytetu imeni Mykhaila Ostrohradskoho. Kremenchuk: KrNU, (5(82)), pp. 156 - 159.

9. Kanilo P. M. Kantserohennist vidpratsovanykh haziv avtomobiliv / P. M. Kanilo, K. V. Kostenko, 
N. V.Vnukova, S. O. Koversun// zb. nauk. pr. / Khark. nats. avtomob.-dor. un-t ; [redkol.: A. Turenko (hol. red.) ta in.]. - Kh. : KhNADU, 2011. - Vyp. 29. - S.160 -167.

10. Hutarevych Yu. F. Ekolohiia ta avtomobilnyi transport: Navchalnyi posibnyk / Yu. F. Hutarevych, D. V. Zerkalov, A. H. Hovorun, A. O. Korpach, L. P. Merzhyievska - K.: Aristei, 2006. - 292 s.

11. Franchuk H. M. Urboekolohiia i tekhnoekolohiia: pidruch. / H. M. Franchuk, O. I. Zaporozhets, H. I. Arkhipova. - K.: Vyd-vo Nats. aviats. un-tu «NAU-druk», 2011. - $496 \mathrm{~s}$.

12. Arkhipova H. I Analiz vplyvu vidpratsovanykh avtomobilnykh haziv na stan atmosfernoho povitria $v$ hustonaselenykh raionakh / H. I. Arkhipova, I. S. Tkachuk, Ye. I. Hlushkov // Visnyk NAU. - 2009. - № 1. - S. 78 - 83.

13. Vnukova N. V. Vplyv avtomobilnykh dorih na ekobezpeku kompleksu «avtomobil-doroha-seredovyshche» / N. V. Vnukova // Skhidno-Yevropeiskyi zhurnal peredovykh tekhnolohii. - 2011. - № 5/3 (53). - S. 43 - 46.

14. Zerkalov D. V. Ekolohichna bezpeka ta okhorona dovkillia: monohrafiia/D.V,Zerkalov. - K.: Osnova, 2012. - $514 \mathrm{~s}$.

15. Uhnenko Ye. B. Vykorystannia pryrodnykh tseolitiv dlia pidvyshchennia efektyvnosti ochyshchennia stokiv $\mathrm{Z}$ avtomobilnykh dorih / Ye. B. Uhnenko, V. O. Yurchenko, N. I. Sorochuk, O. H. Melnikova, M. V. Yachnyk // Avtoshliakhovyk Ukrainy. - 2015. - № 6. - S. 36 - 38.

16. Solovei V. V. Vodorodnye ekotekhnolohyy ynnovatsyonnaia sostavliaiushchaia problemy povishenyia эkolohycheskoi bezopasnosty transportnoi y statsyonarnoi enerhetyky / V. V. Solovei, A. V. Hrytsenko, N. V. Vnukova // Sbornyk nauchnokh trudov KhNADU «Avtomobylnыi transport» - 2012 - №31. - S. 77- 82.

17. Hrytsenko A. V. Snyzhenye emyssyy dyoksyda uhleroda na osnove yspolzovanyia vetrovodorodnykh tekhnolohyi / A. V. Hrytsenko, V. V. Solovei, N. V. Vnukova // Vestnyk KhNADU sb. nauch. tr. - 2014. - Vыр. 64. - S. 96 -102

18. Vnukova N. V. Pokaznyky vplyvu kompleksu ADS na navkolyshnie seredovyshche ta metody yikh otsinky / N. V. Vnukova // Vestnyk KhNADU. - Kharkiv: KhNADU, 2010. - № 51.- S. 173 -179.

19. Vnukova N. V. Vybir ekolohichno znachymykh parametriv avtotransportnykh system dlia otsinky ekolohichnoi nebezpeky prydorozhnoho prostoru / N. V. Vnukova, H. M. Zhelnovach // Ekolohichna bezpeka. - Kremenchuk: KrNU, 2011. - №12. - S. 119 -123.

20. Stepura V. S. Osnovy ekspluatatsii avtomobilnykh dorih i aerodromiv : navch. posib. I V. S. Stepura, A. O. Bieliatynskyi, N. V. Kuzhel. - K.: NAU, 2013. - $204 \mathrm{~s}$.
21. Vnukova N. V. Naukovo-metodolohichni osnovy ekolohichnoi bezpeky kompleksu avtomobildoroha-seredovyshche: avtoref. dys. na zdobuttia nauk. stup. d.t.n.: spets. 21.06.01 «Ekolohichna bezpeka» / Vnukova Nataliia Volodymyrivna. - Kh.: KhNADU. - 2015. - 36 s.

22. Vnukova N. V. Shumove zabrudnennia prymahistralnykh terytorii yak faktor vplyvu na zdorovia naselennia (na prykladi smt Pisochyn Kharkivskoi oblasti) / N. V. Vnukova, H. M. Zhelnovach // Vestnyk KhNADU: sb. nauch. tr. - 2008. - Vyp. 43. - S. 13 - 15.

23. Uhnenko Ye. B. Vyznachennia akustychnoho zabrudnennia prydorozhnoho prostoru ta osnovnykh shumovykh kharakterystyk transportnoho potoku/ Ye. B. Uhnenko, V. S. Havrysh // Naukovo-vyrobnychyi zhurnal Avtomobilni dorohy. Ekolohiia - 2015 - № 6 (248). - S.39 - 41.

24. Vnukova N. V. Otsinka ryzyku akustychnoho ta vibratsiinoho zabrudnennia prydorozhnoho prostoru dilianky avtomobilnoi dorohy / Vnukova N. V., Zhelnovach H. M., Parkhin N. V. // Vestnyk KhNADU sb. nauch. tr. - 2010. - Vyp. 48. - S. 15 -19.

25. Mynyna N. N. Problema snyzhenyia akustycheskoho vozdeistvyia na zhyluiu zastroiku pry proektyrovanyy, stroytelstve y funktsyonyrovanyy transportnykh sooruzhenyi: avtoref. dys. d-ra tekhn. nauk. - SPb., 2012. - 50 s.

26. Yvanov N. Y. Ynzhenernaia akustyka. Teoryia y praktyka borby s shumom / N. Y. Yvanov // uchebnyk. Unyversytetskaia knyha - M.: Lohos 2008. - 424 s.

27. Bazhynov O. V. Hibrydni avtomobili / O. V. Bazhynov, O. P. Smyrnov, S. A. Sierikov, A. V. Hnatov, A. V. Koliesnikov. - Kharkiv: KhNADU, 2008. $-327 \mathrm{~s}$.

28. Leliukhyn A.M. Razrabotka metodov otsenky elektromahnytnykh polei na obъektakh transporta : avtoreferat dys. ... kandydata tekhnycheskykh nauk: 05.22.01 / Leliukhyn Anton Mykhailovych; [Mesto zashchytы: Mosk. hos. avtomobyl.-dorozh. yn-t (tekhn. un-t)]. - Moskva, 2010. - 19 s.

29. Otchet ob otsenke vozdeistvyia na okruzhaiushchuiu sredu 002-17-OVOS / Hosudarstvennoe predpryiatye «BELHYPRODOR» - Mynsk, 2017 - 301 s.

30. Vanchura R. Analiz vmistu vazhkykh metaliv $\mathrm{u}$ pry mahistralnykh zemliakh Nimechchyny ta porivniannia z otrymanymy rezultatamy $v$ Ukraini / R. Vanchura // Suchasni dosiahnennia heodezychnoi nauky ta vyrobnytstva : zbirnyk naukovykh prats Zakhidnoho heodezychnoho tovarystva UTHK I Zakhidne heodezychne tovarystvo Ukrainskoho tovarystva heodezii i kartohrafii, Natsionalnyi universytet "Lvivska politekhnika" - Vypusk 2 (24). - S. 191 - 194, 2012. 
31. Hutarevych Yu. F. Ekolohiia ta avtomobilnyi transport: navchalnyi posibnyk / Yu. F. Hutarevych, D. V. Zerkalov, A. H. Hovorun, A. O. Korpach, L. P. Merzhyievska. - Kyiv: Aristei, 2006 - 292 s.

32. Drive2 [Elektronnyi resurs]. - Rezhym dostupu: https://www.drive2.ru/b/2423164/.

33. Pavlychenko A. V. Transportna ekolohiia. Metodychno-informatsiini materialy do samostiinoho vyvchennia dystsypliny ta vykonannia indyvidualnykh zavdan dlia studentiv napriamu pidhotovky 6.070101 Transportni tekhnolohii (za vydamy transportu) / A. V. Pavlychenko, S. M. Lysytska, O. O. Borysovska, O. V. Demenko. - D.: Natsionalnyi hirnychyi universytet, 2012. - $39 \mathrm{~s}$.
34. Khalylova R. Kh. Ekolohycheskye problemy avtomobylnыkh doroh, proyzvodstvennykh predpryiatyi dorozhnoho stroytelstva y puty ykh reshenyia: avtoreferat dys. ... doktora tekhnycheskykh nauk : 03.00.16 / Khalylova Rakhyma Khamytovna; [Mesto zashchyty: Mosk. hosudarstvennyi unyversytet pryrodoobustroistva]. Moskva, 2001. - $44 \mathrm{~s}$.

35. Abolmasova H. V. Elementy intehralnoho pidkhodu v ekolohichnii otsintsi stanu zabrudnenosti prydorozhnoho prostoru / H. V. Abolmasova, L. A. Pisnia, O. V. Cherba // Ekolohichna bezpeka: problemy i shliakhy vyrishennia: $z b$. nauk, statei XV mizhnar. nauk.-prakt. konf., m. Kharkiv, $9-13$ veres. 2019 r. UKRNDIEP. - PP «Styl-Izdat», 2019. - S.5 - 8.

\title{
Аннотация
}

\section{Комплексная экологическая оценка влияния системы «автомобиль-дорога-среда» на объекты окружающей природной среды}

\section{А.В. Аболмасова, Л.А. Писня, И.А. Черепнев, И.В. Калинин}

В статье раскрыт комплексный подход к оценке влияния деятельности автомобильной дороги на окружающую среду, основанный на применении метода анализа иерархии (МАИ) Т.Саати и реализующий экспертно-аналитический подход. В результате исследования разработана сложная четырехуровневая иерархическая структура в виде пространственной системы «автомобиль-дорогасреда» (АДС). Построение иерархической структуры влияния позволяет наглядно-пространственно понять все взаимовлияния элементов и их взаимозависимость. Уровни иерархической структуры построены в виде логического концепта «цель $\rightarrow$ субкритерии оценки $\rightarrow$ фракторы воздействий $\rightarrow$ параметры воздействий $\rightarrow$ составляющие окружающей среды, подвергающихся воздействию». Значения весовых коэфффициентов, полученных в результате экспертно-аналитического оценивания с применением программы расчетов, реализующую МАИ позволило сделать убедительный вывод в целесообразности учета биотической составляющей придорожного пространства, что до сих пор не учитывалось. Значение полученной оценки общего влияния деятельности АДС на живые организмы составило 50,86\%, поэтому оценка загрязнения воздуха, воды и почвы без учета биотической составляющей не является достаточной и объективной.

Также отмечено, что разработанный комплексный иерархический подход к оценке АДС с применением МАИ, требует дальнейшего уточнения количественных характеристик воздействия на составляющие окружающей среды путем лабораторных исследований биотических компонентов и почвы придорожного пространства по стандартизированным методикам.

Ключевые слова: система «АДС», фракторы влияния, весовой коэфрфициент, окружающей среды, объект воздействия, иерархическая система, экологическая оценка влияния.

\section{Abstract}

\section{Comprehensive ecological assessment of the impact of the «car-road-environment» system on environmental objects}

\author{
G.V. Abolmasova, L.A. Pisnia, I.A. Cherepnov, I.V. Kalinin
}

The article describes a comprehensive approach to the environmental impact of highway activity, which is based on the application of T. Saatie's hierarchy analysis (MAI) method and implements an expert-analytical approach. As a result of the research, a complex four-level hierarchical structure was developed in the form of a spatial system "car-road-environment" (CRE). The construction of a hierarchical structure of influence makes it possible to clearly and spatially understand all the interrelationships of elements and their interdependence. The levels of the hierarchical structure are constructed in the form of a logical concept: "purpose $\rightarrow$ sub-criteria 
of assessment $\rightarrow$ impact factors $\rightarrow$ parameters of impact $\rightarrow$ components of the environment that are exposed ". The values of the weight coefficients obtained as a result of the expert-analytical estimation using the program of calculations implemented by the MAl allowed to make a convincing conclusion in the expediency of taking into account the biotic component of the roadside space, which has not been taken into account so far. The value of the received estimate of the overall impact from the activity of the CRE on living organisms was $50.86 \%$, so the assessment of air, water and soil pollution without taking into account the biotic component is not sufficient and not objective.

It is also noted that a comprehensive hierarchical approach to the evaluation of CRE using the MAI requires further refinement of the quantitative characteristics of the impact on environmental components through laboratory studies of biotic components and soil of the roadside space by standardized methods.

Keywords: CRE system, factors of influence, weight factor, environment, object of influence, hierarchical system, environmental impact assessment.

\section{Бібліографічне посилання/ Bibliography citation: Harvard}

Abolmasova, G. et al. (2019) 'Comprehensive ecological assessment of the impact of the "car-roadenvironment» system on environmental objects', Engineering of nature management, (4(14)), pp. 75 - 85.

Подано до редакції / Received: 02.10.2018 